\title{
Actinomadura scrupuli sp. nov., isolated from rock
}

Correspondence

Soon Dong Lee sdlee@jejunu.ac.kr

\section{Dong Wan Lee and Soon Dong Lee}

\author{
Department of Science Education, Jeju National University, Jeju 690-756, Republic of Korea
}

The genus Actinomadura was established by Lechevalier \& Lechevalier (1970) and its description has been emended by Zhang et al. (1998, 2001) and Miyadoh \& Miyara (2001). Phylogenetically, the genus belongs to the family Thermomonosporaceae, together with the genera Actinocorallia, Actinoallomurus, Spirillospora and Thermomonospora (Zhang et al., 1998; Trujillo \& Goodfellow, 2003; Tamura et al., 2009). At the time of writing, the genus encompasses 40 recognized species and two subspecies (http://www.bacterio.cict.fr/a/actinomadura.html), which were mostly isolated from soil. In this study, we describe the polyphasic taxonomic characterization of an Actinomadura-like strain isolated from rock.

Strain R-Ac12 $1^{\mathrm{T}}$ was isolated from a small stone collected from an agricultural field in Jeju, Republic of Korea. An unwashed stone $(1 \mathrm{~g})$ was ground into powder using a pestle and suspended in $10 \mathrm{ml}$ sterile distilled water. Aliquots of serial dilutions were spread onto starch-casein agar $(1 \%$ soluble starch, $0.03 \%$ casein, $0.2 \% \mathrm{KNO}_{3}, 0.2 \% \mathrm{NaCl}$, $0.2 \% \mathrm{KH}_{2} \mathrm{PO}_{4}, 0.002 \% \mathrm{CaCO}_{3}, 0.005 \% \mathrm{MgSO}_{4} .7 \mathrm{H}_{2} \mathrm{O}$, $0.001 \% \mathrm{FeSO}_{4} \cdot 7 \mathrm{H}_{2} \mathrm{O}$ and $1.8 \%$ agar in distilled water, $\mathrm{pH} 7.2$ ) and the plates were incubated at $30{ }^{\circ} \mathrm{C}$ for 2 weeks. A single colony was selected and further streaked on ISP

The GenBank/EMBL/DDBJ accession number for the 16S rRNA gene sequence of strain R-Ac $121^{\top}$ is FM210339.
(International Streptomyces Project) medium 2 (Shirling \& Gottlieb, 1966). The pure culture was maintained as $20 \%$ $(\mathrm{v} / \mathrm{v})$ glycerol suspensions at -20 and $-80{ }^{\circ} \mathrm{C}$.

For cultural characterization, strain $\mathrm{R}-\mathrm{Ac} 121^{\mathrm{T}}$ was grown for 21 days at $30{ }^{\circ} \mathrm{C}$ on ISP media 2, 3, 4, 5, 6 and 7 (Shirling \& Gottlieb, 1966), nutrient agar (NA; Difco), trypticase soy agar (TSA; Difco), oatmeal-nitrate agar (Prauser \& Bergholz, 1974), humic acid-vitamin (HV) agar (Nonomura \& Ohara, 1969) and water agar (15.0 g agar, $1000 \mathrm{ml}$ tap water). Cell morphology was observed by scanning electron microscopy (model JSM 6700F; JEOL), using cells grown on water agar for 3 weeks. The specimen was fixed for $1 \mathrm{~h}$ with $1 \% \mathrm{OsO}_{4}$ and dehydrated with graded series of ethanol and then ethanol/isoamyl acetate solutions. After critical-point drying with liquid carbon dioxide, the specimen was coated with platinum before observation. Temperature and $\mathrm{pH}$ ranges for growth and $\mathrm{NaCl}$ tolerance were determined on ISP medium 2. Utilization of carbohydrates as sole carbon sources was tested on ISP medium 9 (Shirling \& Gottlieb, 1966), with each filter-sterilized carbon source being used at a final concentration of $1 \%(\mathrm{w} / \mathrm{v})$ for carbohydrates and alcohols and $0.1 \%(\mathrm{w} / \mathrm{v})$ for organic acids. Gram staining, oxidase and catalase activities and degradation abilities were determined using the methods described by Lee et al. (2008). 
Strain R-Ac12 $1^{\mathrm{T}}$ showed good growth on ISP media 2, 3, 4, 5 and 7, NA, oatmeal-nitrate agar, HV agar and water agar and poor growth on ISP medium 6 and TSA. Vegetative mycelium was abundant, branched and twisted. The reverse colour of the colonies was brownish-yellow. Wrinkled arthrospores were borne directly on the substrate mycelium (Fig. 1). Aerial mycelium and soluble pigments were not produced on any of the tested media. Sporangia were not observed. Other physiological and biochemical properties are given in the species description and Table 1.

Genomic DNA was extracted and purified as described by Hopwood et al. (1985). Amplification of the 16S rRNA gene by PCR and sequencing of the PCR product were performed as described by Lee $\&$ Lee (2008). The $16 \mathrm{~S}$ rRNA gene sequence was aligned with corresponding sequences obtained from GenBank by using the CLUSTAL_X program (Thompson et al., 1997). Phylogenetic analyses were performed by using the neighbour-joining (Saitou \& Nei, 1987), maximum-likelihood (Fitch, 1971) and maximumparsimony (Felsenstein, 1981) methods. A phylogenetic tree was constructed by using the NEIGHBOR program in the PHYLIP package (Felsenstein, 1993) from evolutionary distances calculated with the coefficient of Jukes \& Cantor (1969). The robustness of the tree topology was assessed by using bootstrap analysis with 1000 replicated datasets (Felsenstein, 1985).

An almost-complete $16 \mathrm{~S}$ rRNA gene sequence (1402 nt) of strain R-Ac12 $11^{\mathrm{T}}$ determined in this study was compared with the corresponding sequences of members of the genus Actinomadura and related taxa. A neighbour-joining phylogenetic tree based on 16S rRNA gene sequences indicated that strain $\mathrm{R}-\mathrm{Ac} 121^{\mathrm{T}}$ formed a distinct clade within the radiation of the family Thermomonosporaceae (Fig. 2). The highest $16 \mathrm{~S}$ rRNA gene sequence similarity of

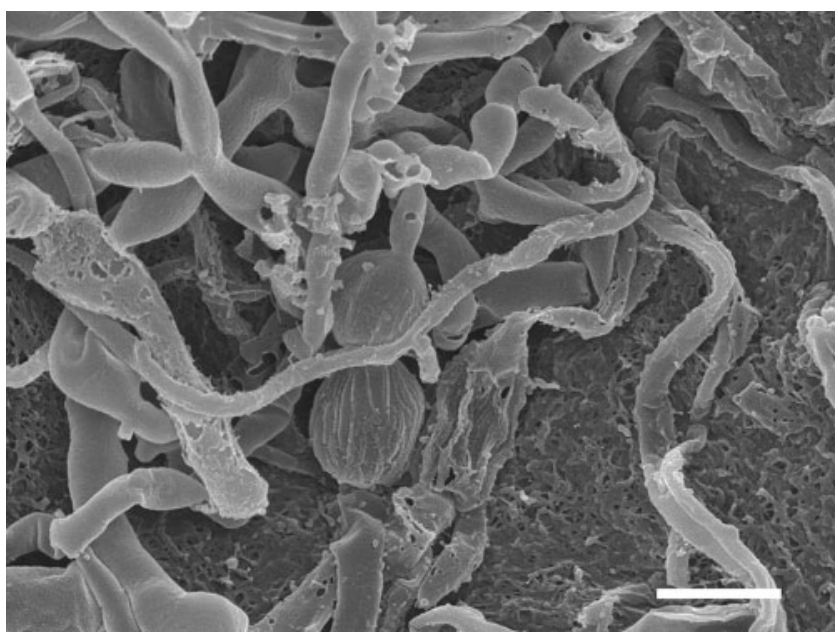

Fig. 1. Scanning electron micrograph of cells of strain R-Ac121 ${ }^{\top}$ grown on water agar for 3 weeks at $30{ }^{\circ} \mathrm{C}$. Bar, $1 \mu \mathrm{m}$. strain $\mathrm{R}-\mathrm{Ac} 121^{\mathrm{T}}$ to type strains of recognized species of the Thermomonosporaceae was found with Spirillospora rubra (97.3\% sequence similarity), Actinoallomurus purpureus $(97.0 \%)$, Actinomadura alba (96.5\%), Actinomadura fibrosa $(96.5 \%)$ and Actinomadura echinospora (96.4\%).

Cell biomass for chemotaxonomic analyses was obtained from cultures grown in ISP 2 broth for 7 days at $30{ }^{\circ} \mathrm{C}$. The isomer of diaminopimelic acid in the cell-wall peptidoglycan was determined by the method of Staneck \& Roberts (1974). Whole-cell sugars were analysed as described by Saddler et al. (1991). Respiratory quinones were extracted according to Collins (1985) and identified by HPLC (Kroppenstedt, 1985). Analysis of polar lipids was performed by TLC as described previously (Minnikin et al., 1975). Cellular fatty acid methyl esters were prepared and analysed according to the standard protocol of the Microbial Identification System (version 6; MIDI).

Strain R-Ac12 $1^{\mathrm{T}}$ contained meso-diaminopimelic acid as the diagnostic diamino acid and rhamnose, glucose, ribose, xylose and arabinose as whole-cell sugars. Madurose (3-Omethyl D-galactose), a characteristic sugar found in most species of the family Thermomonosporaceae (Lechevalier \& Gerber, 1970), was not detected in our analysis by GC. Like strain R-Ac121 $1^{\mathrm{T}}$, a few strains of the genus Thermomonospora and thermophilic Actinomadura species either lack madurose or synthesize it in trace amounts (Kroppenstedt, 1987). The polar lipids included diphosphatidylglycerol, phosphatidylglycerol and phosphatidylinositol. The menaquinone composition was MK-9 $\left(\mathrm{H}_{6}\right)$, MK-9 $\left(\mathrm{H}_{8}\right)$ and MK-9 $\left(\mathrm{H}_{4}\right)$ in the ratio of $80: 14: 6$. The cellular fatty acid profile of strain R-Ac121 $1^{\mathrm{T}}$ consisted of saturated, unsaturated, branched and 10-methyl fatty acids. The cellular fatty acid composition was iso- $\mathrm{C}_{16: 0}(23.8 \%)$, $\mathrm{C}_{16: 0} \quad(11.8 \%), \mathrm{C}_{17: 1} \omega 8 \mathrm{c}$ (10.7\%), 10-methyl $\mathrm{C}_{17: 0}$ (10.7\%), $\mathrm{C}_{18: 1} \omega 9 c \quad(8.7 \%), \quad 10$-methyl $\mathrm{C}_{18: 0} \quad(6.6 \%)$, $\mathrm{C}_{17: 0} \quad(4.4 \%), \mathrm{C}_{18: 0} \quad(4.3 \%), \mathrm{C}_{15: 0} \quad(4.2 \%), \mathrm{C}_{16: 1} \omega 7 c$ and/or iso- $\mathrm{C}_{15: 0} \quad 2-\mathrm{OH} \quad(3.6 \%), \mathrm{C}_{19: 1} \omega 11 \mathrm{c}$ and/or unknown $18.756(1.2 \%)$, iso- $\mathrm{C}_{14: 0}(1.1 \%)$ and iso- $\mathrm{C}_{18: 0}$ $(1.1 \%)$. The $\mathrm{G}+\mathrm{C}$ content of the DNA, as determined by HPLC (Mesbah et al., 1989), was $71.8 \mathrm{~mol} \%$.

The five genera Actinoallomurus, Actinocorallia, Actinomadura, Spirillospora and Thermomonospora of the family Thermomonosporaceae are similar in most of their chemotaxonomic characteristics with the exception of polar lipid profiles (Kroppenstedt, 1985; Zhang et al., 2001; Tamura et al., 2009). However, they can be differentiated from one another by a combination of morphological and chemotaxonomic features. The 16S rRNA gene tree (Fig. 2) reveals that strain $\mathrm{R}-\mathrm{Ac} 121^{\mathrm{T}}$ formed a distinct sublineage within the family Thermomonosporaceae. Of its phylogenetic neighbours, S. rubra showed the highest sequence similarity $(97.3 \%)$ to strain R-Ac12 $1^{\mathrm{T}}$ but it, together with Spirillospora albida, differs morphologically from strain RAc121 $1^{\mathrm{T}}$ in that they form sporangia containing motile spores. Actinomadura fibrosa produces thick fibres on 
Table 1. Characteristics that differentiate strain R-Ac $121^{\top}$ from its phylogenetic neighbours

Taxa: 1, R-Ac121 ${ }^{\mathrm{T}}$; 2, Actinoallomurus purpureus TTN02-30 ${ }^{\mathrm{T}}$ (data from Tamura et al., 2009); 3, Actinomadura alba YIM 45681 ${ }^{\mathrm{T}}$ (Wang et al., 2007); 4, Actinomadura echinospora DSM $43163^{\mathrm{T}}$ (Miyadoh et al., 1990; Holt et al., 1994; Wang et al., 2007); 5, Actinomadura fibrosa ATCC 49459 ${ }^{\mathrm{T}}$ (Mertz \& Yao, 1990; Wink et al., 2003); 6, Spirillospora (Vobis \& Kothe, 1989; Wink, 2001; Zhang et al., 2001). +, Positive; W, weakly positive; -, negative; ND, no data available.

\begin{tabular}{|c|c|c|c|c|c|c|}
\hline Characteristic & 1 & 2 & 3 & 4 & 5 & 6 \\
\hline \multicolumn{7}{|l|}{ Colour of growth on ISP } \\
\hline \multicolumn{7}{|l|}{4} \\
\hline Substrate mycelium & Brownish-yellow & $\begin{array}{l}\text { Pale yellow to } \\
\text { reddish-purple }\end{array}$ & Greyish-yellow & Greyish-yellow & Brown & $\begin{array}{l}\text { Beige or red to } \\
\text { reddish-brown }\end{array}$ \\
\hline Diffusible pigment & None & None & None & Tan & None & None \\
\hline Production of spores & + & + & + & + & - & - \\
\hline Motility of spores & - & - & - & - & - & + \\
\hline $\begin{array}{l}\text { Optimal temperature } \\
\left({ }^{\circ} \mathrm{C}\right)\end{array}$ & 30 & $25-30$ & 28 & $35-40$ & 37 & 25 \\
\hline \multicolumn{7}{|l|}{ Utilization of: } \\
\hline Glycerol & + & + & - & $\mathrm{W}$ & ND & ND \\
\hline D-Mannitol & - & ND & + & + & - & $+^{*}$ \\
\hline Liquefaction of gelatin & + & + & + & + & + & $-{ }^{*}$ \\
\hline Hydrolysis of starch & - & + & + & - & + & ND \\
\hline Nitrate reduction & + & - & + & - & + & - \\
\hline Polar lipids $\dagger$ & DPG, PG, PI & DPG, PG & DPG, PG, PI, PIM & DPG, PG, PI, PIM & DPG, PI & DPG, PI, PIM \\
\hline Major menaquinone(s) & $9\left(\mathrm{H}_{6}\right)$ & $9\left(\mathrm{H}_{6}\right), 9\left(\mathrm{H}_{8}\right)$ & $9\left(\mathrm{H}_{4}\right), 9\left(\mathrm{H}_{6}\right), 9\left(\mathrm{H}_{2}\right)$ & $9\left(\mathrm{H}_{6}\right)$ & $9\left(\mathrm{H}_{6}\right)$ & $9\left(\mathrm{H}_{4}\right), 9\left(\mathrm{H}_{6}\right)$ \\
\hline $\begin{array}{l}\text { Major fatty acids } \\
(>10 \%)\end{array}$ & $\begin{array}{c}\mathrm{i}-\mathrm{C}_{16: 0}, \mathrm{C}_{16: 0} \\
\mathrm{C}_{17: 1} \omega 8 c, 10-\mathrm{Me} \\
\mathrm{C}_{17: 0}\end{array}$ & $\mathrm{i}-\mathrm{C}_{16: 0}$, ai- $\mathrm{C}_{17: 0}$ & $\begin{array}{r}\mathrm{i}-\mathrm{C}_{16: 1} \mathrm{H}, \mathrm{C}_{17: 1} \omega 8 c \\
\mathrm{C}_{16: 0}, 10-\mathrm{Me} \mathrm{C}_{17: 0}\end{array}$ & $\begin{array}{c}\mathrm{C}_{17: 0}, \mathrm{i}-\mathrm{C}_{18: 0}, 10- \\
\text { Me } \mathrm{C}_{17: 0}, \mathrm{TBSA}\end{array}$ & $\mathrm{i}-\mathrm{C}_{16: 0}$, TBSA & $\begin{array}{l}\mathrm{C}_{16: 0}, \mathrm{C}_{18: 1} \\
\mathrm{i}-\mathrm{C}_{16: 0}, \text { TBSA }\end{array}$ \\
\hline Cell-wall sugar(s)§ & $\begin{array}{c}\text { Ara, Glc, Rha, Rib, } \\
\text { Xyl }\end{array}$ & Mad, Gal & $\begin{array}{l}\text { Gal, Glc Mad, Rib, } \\
\text { Xyl }\end{array}$ & Mad & $\begin{array}{c}\text { Gal, Glc, Mad, } \\
\text { Man, Rib }\end{array}$ & Mad \\
\hline
\end{tabular}

${ }^{*}$ Detected only in the type strain of Spirillospora albida (Vobis \& Kothe, 1989; Wink, 2001; Zhang et al., 2001).

$\nmid$ DPG, Diphosphatidylglycerol; PG, phosphatidylglycerol; PI, phosphatidylinositol; PIM, phosphatidylinositol mannosides.

$\ddagger$ i, iso-branched; ai, anteiso-branched; Me, methyl; TBSA, tuberculostearic acid (10-methyl $\left.\mathrm{C}_{18: 0}\right)$.

$\S$ Ara, Arabinose; Gal, galactose; Glc, glucose; Mad, madurose; Man, mannose; Rha, rhamnose; Rib, ribose; Xyl, xylose.

the substrate mycelium, but strain $\mathrm{R}-\mathrm{Ac} 121^{\mathrm{T}}$ produces wrinkled arthrospores (Fig. 1). Actinomadura alba, Actinomadura echinospora and members of the genus Actinoallomurus are similar to strain $\mathrm{R}-\mathrm{Ac} 121^{\mathrm{T}}$ in that they produce arthrospores, but they can be differentiated from the isolate in some chemotaxonomic characters (i.e. cellwall sugars, menaquinones and fatty acids). Differential characteristics of strain R-Ac12 $11^{\mathrm{T}}$ from its phylogenetic neighbours are given in Table 1 .

On the basis of the morphological, chemotaxonomic and phylogenetic data, strain R-Ac12 $1^{\mathrm{T}}$ represents a novel species of the genus Actinomadura, for which the name Actinomadura scrupuli sp. nov. is proposed.

\section{Description of Actinomadura scrupuli sp. nov.}

Actinomadura scrupuli (scru'pu.li. L. gen. n. scrupuli of a small stone, referring to the isolation of the type strain).

Aerobic, Gram-stain-positive. Cells grow well on ISP media 2, 3, 4, 5 and 7, NA, oatmeal-nitrate agar, HV agar and water agar plates and show poor growth on ISP medium 6 and TSA. The organism forms abundant vegetative mycelium that is branched and twisted. The reverse colour of the colonies is brownish-yellow. Aerial mycelium and soluble pigments are not produced on any of the tested media. Wrinkled arthrospores $(0.9-1.1 \mu \mathrm{m}$ in diameter) are produced directly from the substrate mycelium on water agar. Sporangia are not observed. Growth occurs at 


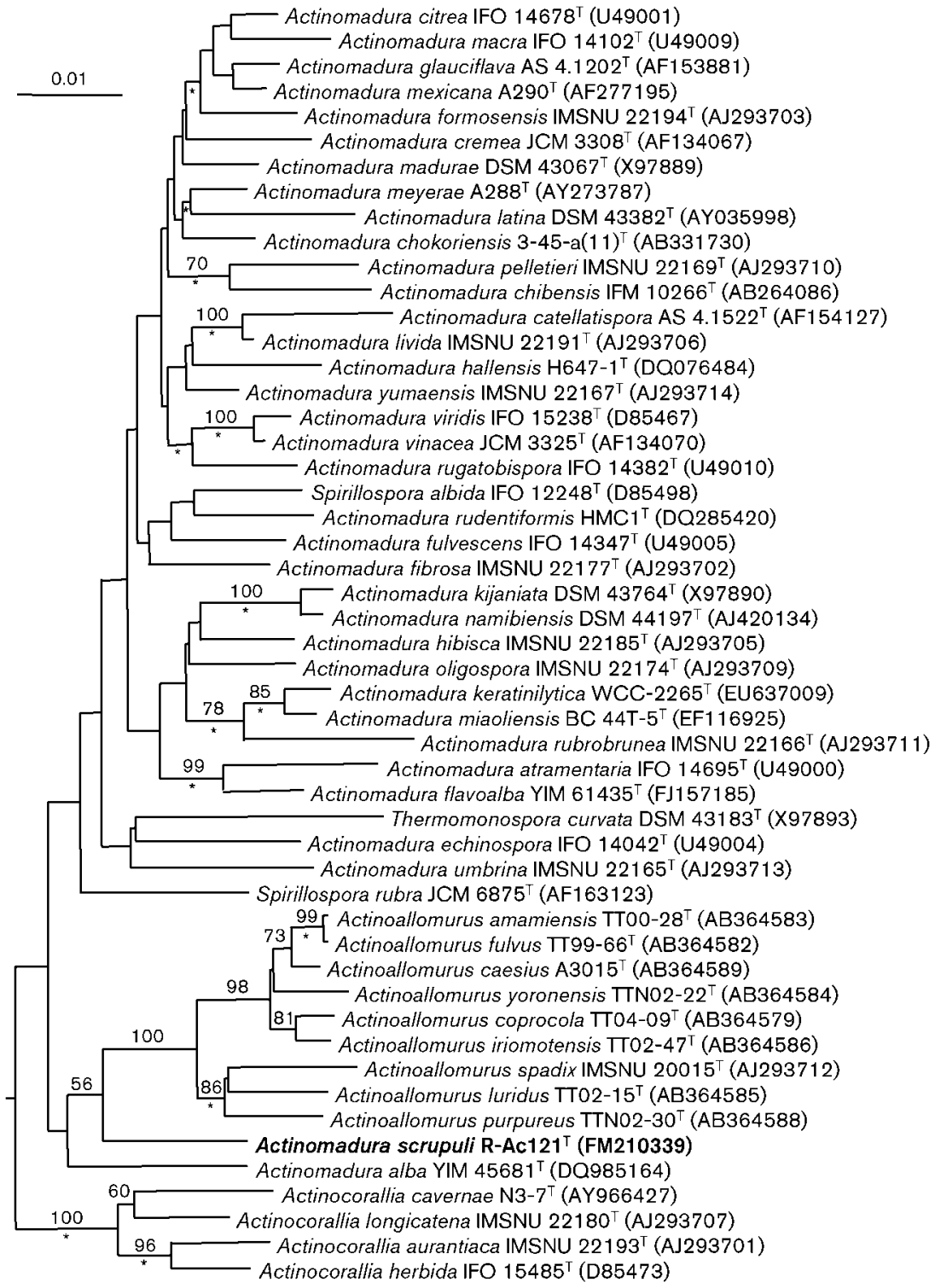

Fig. 2. Phylogenetic tree based on $16 \mathrm{~S}$ rRNA gene sequences showing the position of strain R-Ac1 $121^{\top}$ within the radiation of the family Thermomonosporaceae. The tree was constructed from an evolutionary distance matrix by using the neighbour-joining method. The sequence of Nocardiopsis dassonvillei DSM $43111^{\top}$ (GenBank accession no. X97886; not shown) was used as an outgroup. Asterisks represent branches also found in both maximum-likelihood and maximum-parsimony trees. Numbers at nodes indicate levels of bootstrap support ( $>50 \%$ ) based on a neighbour-joining analysis of 1000 resampled datasets. Bar, 0.01 substitutions per site.
$\mathrm{pH}$ 6.1-8.1. The temperature range for growth is $20-30{ }^{\circ} \mathrm{C}$. Good growth occurs in the absence of $\mathrm{NaCl}$. Nitrate is reduced to nitrite. Aesculin and gelatin are degraded but not casein, cellulose, chitin, DNA, elastin, hypoxanthine, starch, L-tyrosine or xanthine. Acetate, adonitol, Larabinose, cellobiose, dextran, D-fructose, D-galactose, Dglucose, glycerol, lactose, DL-malate, melibiose, L-rhamnose, D-sorbitol, L-sorbose, succinate, sucrose, trehalose and $\mathrm{D}$-xylose can be utilized as carbon sources, but $\mathrm{D}$ arabinose, benzoate, citrate, dulcitol, meso-erythritol, formate, myo-inositol, inulin, D-mannose, melezitose, methyl $\alpha$-D-glucoside, methyl $\alpha$-D-mannoside, D-mannitol, raffinose, L-ribose, salicin, L-tartrate and D-xylitol are not utilized. meso-Diaminopimelic acid and rhamnose, glucose, ribose, xylose and arabinose are the diagnostic diamino acid and whole-cell sugars, respectively. The polar lipids include diphosphatidylglycerol, phosphatidylglycerol and phosphatidylinositol. The major menaquinone is
MK-9 $\left(\mathrm{H}_{6}\right)$. The predominant fatty acids are iso- $\mathrm{C}_{16: 0}$, $\mathrm{C}_{16: 0}, \mathrm{C}_{17: 1} \omega 8 c$ and 10-methyl $\mathrm{C}_{17: 0}$. The $\mathrm{G}+\mathrm{C}$ content of the DNA of the type strain is $71.8 \mathrm{~mol} \%$.

The type strain, R-Ac121 ${ }^{\mathrm{T}}$ (=KCTC $19488^{\mathrm{T}}=\mathrm{DSM}$ $45225^{\mathrm{T}}$ ), was isolated from a small stone in Jeju, Republic of Korea.

\section{Acknowledgements}

This work was supported by the 21C Frontier Microbial Genomics and Application Center Program, Ministry of Science \& Technology, Republic of Korea.

\section{References}

Collins, M. D. (1985). Analysis of isoprenoid quinones. Methods Microbiol 18, 329-366. 
Felsenstein, J. (1981). Evolutionary trees from DNA sequences: a maximum likelihood approach. J Mol Evol 17, 368-376.

Felsenstein, J. (1985). Confidence limits on phylogenies: an approach using the bootstrap. Evolution 39, 783-791.

Felsenstein, J. (1993). PHYLIP (phylogeny inference package), version 3.51c. Distributed by the author. Department of Genome Sciences, University of Washington, Seattle, USA.

Fitch, W. M. (1971). Toward defining the course of evolution: minimum change for a specific tree topology. Syst Zool 20, 406-416.

Holt, J. G., Krieg, N. R., Sneath, P. H. A., Stanley, J. T. \& Williams, S. T. (1994). In Bergey's Manual of Determinative Bacteriology, 9th edn, pp. 690-691. Baltimore: Williams \& Wilkins.

Hopwood, D. A., Bibb, M. J., Chater, K. F., Kieser, T., Bruton, C. J., Kieser, H. M., Lydiate, D. J., Smith, C. P., Ward, J. M. \& Schrempf, H. (1985). Genetic Manipulation of Streptomyces: a Laboratory Manual. Norwich: John Innes Foundation.

Jukes, T. H. \& Cantor, C. R. (1969). Evolution of protein molecules. In Mammalian Protein Metabolism, vol. 3, pp. 21-132. Edited by H. N. Munro. New York: Academic Press.

Kroppenstedt, R. M. (1985). Fatty acid and menaquinone analysis of actinomycetes and related organisms. In Chemical Methods in Bacterial Systematics, pp. 173-199. Edited by M. Goodfellow \& D. E. Minnikin. London: Academic Press.

Kroppenstedt, R. M. (1987). Chemische Untersuchungen an Actinomycetales und verwandten Taxa, Korrelation von Chemosystematik und Phylogenie. Habilitationsschrift, Technische Hochschule Darmstadt, Darmstadt, Germany (in German).

Lechevalier, M. P. \& Gerber, N. N. (1970). The identity of madurose with 3-O-methyl-D-galactose. Carbohydr Res 13, 451-454.

Lechevalier, M. P. \& Lechevalier, H. A. (1970). Chemical composition as a criterion in the classification of aerobic actinomycetes. Int J Syst Bacteriol 20, 435-443.

Lee, D. W. \& Lee, S. D. (2008). Aeromicrobium ponti sp. nov., isolated from seawater. Int J Syst Evol Microbiol 58, 987-991.

Lee, J.-E., Seo, J. P., Lee, D. W., Ko, Y. H. \& Lee, S. D. (2008). Terrabacter lapilli sp. nov., a novel actinomycete isolated from stone. Int J Syst Evol Microbiol 58, 1084-1088.

Mertz, F. P. \& Yao, R. C. (1990). Actinomadura fibrosa sp. nov. isolated from soil. Int J Syst Bacteriol 40, 28-33.

Mesbah, M., Premachandran, U. \& Whitman, W. B. (1989). Precise measurement of the $\mathrm{G}+\mathrm{C}$ content of deoxyribonucleic acid by highperformance liquid chromatography. Int J Syst Bacteriol 39, 159-167.

Minnikin, D. E., Alshamaony, L. \& Goodfellow, M. (1975). Differentiation of Mycobacterium, Nocardia, and related taxa by thin layer chromatographic analysis of whole-cell methanolysates. J Gen Microbiol 88, 200-204.

Miyadoh, S. \& Miyara, T. (2001). Family Thermomonosporaceae. In Identification Manual of Actinomycetes, pp. 281-291. Edited by the Society for Actinomycetes. Tokyo: Business Center for Academic Societies.

Miyadoh, S., Amano, S., Tohyama, H. \& Shomura, T. (1990). A taxonomic review of the genus Microbispora and a proposal to transfer two species to the genus Actinomadura and to combine ten species into Microbispora rosea. J Gen Microbiol 136, 1905-1913.
Nonomura, H. \& Ohara, Y. (1969). Distribution of the actinomycetes in soil. VI. A culture method effective for both preferential isolation and enumeration of Microbispora and Streptosporangium strains in soil. Part 1. J Ferment Technol 38, 405-409.

Prauser, H. \& Bergholz, M. (1974). Taxonomy of actinomycetes and screening for antibiotic substances. Postepy Hig Med Dosw 28, 441457.

Saddler, G. S., Tavecchia, P., Lociuro, S., Zanol, M., Colombo, L. \& Selva, E. (1991). Analysis of madurose and other actinomycete whole cell sugars by gas chromatography. J Microbiol Methods 14, 185-191.

Saitou, N. \& Nei, M. (1987). The neighbor-joining method: a new method for reconstructing phylogenetic trees. Mol Biol Evol 4, 406425.

Shirling, E. B. \& Gottlieb, D. (1966). Methods for characterization of Streptomyces species. Int J Syst Bacteriol 16, 313-340.

Staneck, J. L. \& Roberts, G. D. (1974). Simplified approach to identification of aerobic actinomycetes by thin-layer chromatography. Appl Microbiol 28, 226-231.

Tamura, T., Ishida, Y., Nozawa, Y., Otoguro, M. \& Suzuki, K. (2009). Transfer of Actinomadura spadix Nonomura and Ohara 1971 to Actinoallomurus spadix gen. nov., comb. nov., and description of Actinoallomurus amamiensis sp. nov., Actinoallomurus caesius sp. nov., Actinoallomurus coprocola sp. nov., Actinoallomurus fulvus sp. nov., Actinoallomurus iriomotensis sp. nov., Actinoallomurus luridus sp. nov., Actinoallomurus purpureus sp. nov. and Actinoallomurus yoronensis sp. nov. Int J Syst Evol Microbiol 59, 1867-1874.

Thompson, J. D., Gibson, T. J., Plewniak, F., Jeanmougin, F. \& Higgins, D. G. (1997). The CLUSTAL_X windows interface: flexible strategies for multiple sequence alignment aided by quality analysis tools. Nucleic Acids Res 25, 4876-4882.

Trujillo, M. E. \& Goodfellow, M. (2003). Numerical phenetic classification of clinically significant aerobic sporoactinomycetes and related organisms. Antonie van Leeuwenhoek 84, 39-68.

Vobis, G. \& Kothe, H.-W. (1989). Genus Spirillospora Couch 1963, $61^{\mathrm{AL}}$. In Bergey's Manual of Systematic Bacteriology, vol. 4, pp. 25432545. Edited by S. T. Williams, M. E. Sharpe \& J. G. Holt. Baltimore: Williams \& Wilkins.

Wang, Y.-X., Zhi, X.-Y., Chen, H.-H., Zhang, Y.-Q., Tang, S.-K., Jiang, C.-L., Xu, L.-H. \& Li, W.-J. (2007). Actinomadura alba sp. nov., isolated from soil in Yunnan, China. Int J Syst Evol Microbiol 57, 1735-1739.

Wink, J. (2001). The Actinomycetales. An Order in the Class of Actinobacteria Important to the Pharmaceutical Industry - Electronic Manual. CD-ROM. Frankfurt: Aventis Pharma.

Wink, J., Kroppenstedt, R. M., Seibert, G. \& Stackebrandt, E. (2003). Actinomadura namibiensis sp. nov. Int J Syst Evol Microbiol 53, 721724 .

Zhang, Z., Wang, Y. \& Ruan, J. (1998). Reclassification of Thermomonospora and Microtetraspora. Int J Syst Bacteriol 48, 411422.

Zhang, Z., Kudo, T., Nakajima, Y. \& Wang, Y. (2001). Clarification of the relationship between the members of the family Thermomonosporaceae on the basis of 16S rDNA, 16S-23S rRNA internal transcribed spacer and $23 \mathrm{~S}$ rDNA sequences and chemotaxonomic analyses. Int J Syst Evol Microbiol 51, 373-383. 